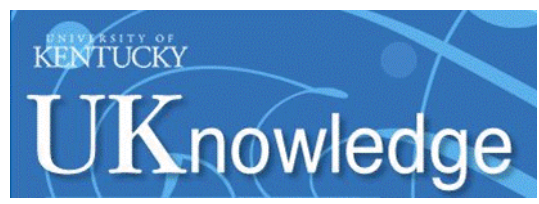

University of Kentucky

UKnowledge

\title{
Order Matters: Typology of Dual-Degreed Law Librarians
}

James M. Donovan

University of Kentucky Rosenberg College of Law, james.donovan@uky.edu

Follow this and additional works at: https://uknowledge.uky.edu/law_facpub

Part of the Law Librarianship Commons

Right click to open a feedback form in a new tab to let us know how this document benefits you.

\section{Repository Citation}

Donovan, James M., "Order Matters: Typology of Dual-Degreed Law Librarians" (2014). Law Faculty Scholarly Articles. 681.

https://uknowledge.uky.edu/law_facpub/681

This Article is brought to you for free and open access by the Law Faculty Publications at UKnowledge. It has been accepted for inclusion in Law Faculty Scholarly Articles by an authorized administrator of UKnowledge. For more information, please contact UKnowledge@lsv.uky.edu. 


\section{Order Matters: Typology of Dual-Degreed Law Librarians}

\section{Notes/Citation Information}

James M. Donovan, Order Matters: Typology of Dual-Degreed Law Librarians, 33(1) Legal Reference Serv. Q. 1-37 (2014). 


\title{
Order Matters: Typology of Dual-Degreed Law Librarians
}

\author{
JAMES M. DONOVAN \\ University of Kentucky College of Law, Lexington, Kentucky, USA
}

\begin{abstract}
To a great extent, law librarianship has regarded the dual-degreed librarian as too familiar and uncomplicated to merit extended attention. The present discussion challenges this assumed simplicity. The goal of professional education is to work on deeper personal levels to create a particular identity and to inculcate specific values necessary to the successful practice of the vocation. Such fundamental effects are neither easily erased nor superseded by a later professional indoctrination. Understood in this way, professional education produces an outcome that defies the commutative property. Order matters. Librarians who go to law school (i.e., "libyers") should be discernible from lawyers who attend library school ("lawbrarians"), with consequences for the practice of law librarianship. Using data describing members of the American Association of Law Libraries, this study tests the bypothesis that, given the fundamental levels at which professional enculturation operates, when an individual undergoes professional formation more than once the values of the first training regime will typically have the more profound impact on the general personality.
\end{abstract}

KEYWORDS professional education, identity, ethics, personality, enculturation

\section{INTRODUCTION}

Law librarianship is unique among the academic specialties. Although dual degrees are not uncommon among librarians, no other specialty routinely assumes that the librarian will hold the terminal degree in the discipline for which she provides services. Medical librarians are not required to be MDs,

(C) James M. Donovan

Address correspondence to James M. Donovan, University of Kentucky College of Law, 620 S. Limestone St., Lexington, KY 40506, USA. E-mail: james.donovan@uky.edu 
nor business librarians, MBAs. Yet anyone who aspires to become a law librarian will have a major hurdle to overcome without a JD, especially if aiming for a public services position within an academic setting. ${ }^{1}$ Despite being a commonplace, little is known about these dual-degreed law librarians. This lack of knowledge may be an expensive indulgence. According to American Association of Law Libraries (AALL) estimates, the subset of dual-degreed librarians constitutes $33.2 \%$ of its members, and $55.1 \%$ of those within academic law libraries. ${ }^{2}$ With such numbers, any associated dynamics that set this group apart would impact the profession as a whole.

This essay begins to fill this gap in our self-knowledge by challenging the assumed homogeneity of dual-degreed law librarians. Given the characteristics of professional education itself, the order of degree acquisition can be anticipated to exert a subtle but consistent influence on how the dual-degreed librarian approaches common problems. ${ }^{3}$ The inverted histories of professional socialization would then yield two related, but distinguishable, kinds: the librarian-lawyer (the "libyer"), whose primary identification is as a librarian who later obtained specialized legal training; and the lawyer-librarian ("lawbrarian"), who trained initially as a legal expert and subsequently finished with library science education. As discussed in the following, differences arising from these complementary occupational paths may explain emerging trends within the field of law librarianship.

\section{PROFESSIONS}

"Professional" is a term much abused, often serving as a simple contrastive term against "amateur." 4 If you get paid to do something, then you are a

1 Stephen Young has recently argued against the need for law librarians to hold the JD. Stephen Young, The Dual Degree: A Requirement in Search of a Justification, 17 AALL Spectrum 7 (Dec. 2012). Robert Hauptman uses this scenario-the nonlibrarian, non-JD library worker in a state library providing legal information to a senator-as one of his ethical case studies. Robert Hauptman, Ethical Challenges in Librarianship 18-19 (1988). From his previous discussion - "a competent paraprofessional probably can do virtually any job within the library field" (p. 15)—it is clear where Hauptman's sympathies lie.

2 Am. Assn. L. Libr., AALL Biennial Salary Survey 10, S-2 (American Association of Law Libraries 2011).

3 An instructive precedent for this claim can perhaps be found in the study of secondlanguage acquisition, and the phenomenon of interlanguage, in which the native language and the subsequent target language interact to create a new language system, elements of which are not reducible to those in either the first or second languages. See Yuko G. Butler \& Kenji Hakuta, Bilingualism and Second Language Acquisition, in The Handbook of Bilingualism 114, 129-134 (2006).

$4 \quad$ Abraham Flexner, Is Social Work a Profession?, School \& Soc. 901 (1915) ("The word 'profession' or 'professional' may be loosely or strictly used. In its broadest significance it is simply the opposite of the word 'amateur'"). 
"professional." In this sense the word becomes a synonym for any job by which one earns a livelihood.

But ordinary speakers also use the term in a more restricted sense, especially as a noun (i.e., the claim that "I am a professional" conveys something different than "I am a professional cook"). Staking out this semantic boundary is the goal of the present section. What is it about a "profession" that sets it apart from other forms of work life? This question must be addressed because while few would challenge the professional standing of law, the status of librarianship is more tenuous. If librarians are not professionals in a relevant sense of the term, then an argument for a typology of law librarians based on sequential courses of professional education would be a nonstarter.

The literature on the professions normally focuses on a cluster of structural elements, the possession of which serves to mark an occupational group as a true "profession." The contours of this claim can vary, but in Ernest Greenwood's influential account occupations in this esteemed class are thought to possess "(1) systematic theory, (2) authority, (3) community sanction, (4) ethical codes, and (5) a culture." ${ }^{6}$ These are qualities over and above the simple learning of the technical expertise to perform tasks, and moreover they build upon one another. Systematic theory first provides an explicit framework that not only explains received practices, but allows the technique's successful application to novel problems. Theory is what separates the mechanic from an engineer. Theory-based expertise expands the sphere of the practitioner's repertoire of responses, conferring autbority in those situations, as compared to "the layman's relative ignorance." As usually conceived, the knowledge gap generating recognized authority is a qualitative and not a quantitative difference.

Community sanction arises when society confers an exclusive privilege to authorized practitioners to control the practice within its field of expertise. Given the importance of the work they do, society regulates doctors and lawyers, but that responsibility has been delegated. Other doctors and lawyers, and not governmental agents, determine who shall have the needed licenses and on what terms and conditions. This combination of both exclusive knowledge and social power drives the need to create ethical codes:

5 Although portrayed dichotomously here, in a fuller account there would be a middle ground between the states of amateur and professional. For example, at one time the Olympics were restricted to amateurs, defined as "one who participates and always has participated in sport as an avocation without material gain of any kind." International Olympic Committee, Eligibility Rules 5 (1964), http://www.olympic.org/Documents/Olympic\%20 Charter/Olympic_Charter_through_time/1964-Olympic_Charter_Eligibility_Rules_of_the_IOC. pdf. Anyone "awarded a scholarship mainly for his athletic ability" or "who indicates his intention of becoming a professional" was ruled ineligible for Olympic participation. $I d$. at 6 . In such terms, one can lose one's amateur status without becoming a professional.

6 Ernest Greenwood, Attributes of a Profession, 2 Soc. Work 45, 45 (1957).

$7 \quad$ Id 
The professions, as we see them, differ from other occupations in the sense that they consist of a set of knowledge areas and techniques which are specialized to a point where the client or lay person is not able to understand or evaluate them. Thus, an asymmetrical relationship exists between the parties; and the client must depend upon the practitioner to protect his interest. The profession, on the other hand, must take the responsibility for this protection by maintaining high standards of excellence; by espousing an ideal of service, altruism and sacrifice, rather than a commercial motive; and, at the same time, maintaining its prerogative as the sole judge of performance. In order to maintain these normative standards and to avoid the possibility of exploitation of the client, the profession must develop a series of self-administered control systems. ${ }^{8}$

With these indicia in mind, we should not be surprised that opinions have varied over whether librarianship belongs in the august category of the recognized professions. More than one hundred and thirty years ago, when the modern discipline of librarianship commenced, Melvil Dewey boldly proclaimed that "The time has at last come when a librarian may, without assumption, speak of his occupation as a profession." Just as confidently, however, Pierce Butler concludes that the "whole course of library history hitherto seems to imply that it is not" a profession, ${ }^{10}$ and William Goode admits that he is "doubtful that the librarians will become full-fledged professionals." 11 At best, it perhaps belongs among the "semi-professions," whose "training is shorter, their status is less legitimated, their right to privileged communication less established, there is less of a specialized body of knowledge, and they have less autonomy from supervision or societal control than 'the' professions." 12

Writers who would deny professional standing to librarians can point to several anomalies, including that (1) "the parallels between librarianship and the not-yet-professions are as great as those which librarians had so assiduously been trying to draw between librarianship and that 'in' group"; (2) "neither the public nor the field itself is convinced that successful achievement in librarianship must be based on the systematic knowledge of doctrine that can only be acquired through the long period of prescribed training"; and (3) "the failure - or the reasoned refusal—of the librarian to prescribe and to dictate goes back in part to the absence of a body of knowledge

\footnotetext{
8 Basil J. Sherlock \& Richard T. Morris, The Evolution of the Professional: A Paradigm, 37 Soc. Inquiry 27, 43 (1967).

9 Melvil Dewey, The Profession, 1 Am. Libr. J. 5-6 (Sept. 30, 1876).

10 Pierce Butler, Librarianship as a Profession, 21 Libr. Q. 235, 245 (1951).

11 William J. Goode, The Librarian: From Occupation to Profession?, 31 Libr. Q. 306, 307 (1961).

12 Amitai Etzioni, The Semi-Professions and Their Organization v (Macmillan 1969).
} 
unique to the librarian on which he or she can base the judgment of what is best for the client."13

The difficulties of judging librarianship to be a profession on these terms may be illustrated with the contrast between the primary organizational representative of librarians, the American Library Association (ALA), and that for traditional professions such as law's American Bar Association and medicine's American Medical Association. Although the latter limit their memberships to practitioners, with those outside that category assigned to lower tiers with limited privileges, ${ }^{14}$ ALA welcomes as members any "individuals, organizations and non-profits, and businesses interested in working together to ensure a stable future of libraries, librarians, and the profession."15 AALL has a similar open-membership policy in which active membership, with full voting privileges, is available to anyone "interested in the objectives of the Association."16 While nonexclusive membership may yield some public relations advantages, the policy itself undermines the self-presentation of librarianship as a profession. Library organizations fail to display the gatekeeping function expected of professions, that is, controlling who can vote and shape the standards of practice. The outcome, as noted by Butler, is that the library professional association "is more a labor union than a learned society." 17

Perhaps the most significant manifestation of this ill-defined identity has been ALA's failure to adopt "a consistent stand in defending the master of library science (MLS) as the professional qualification" needed to call oneself a librarian, or to work in libraries. ${ }^{18}$ The requirement of an MLS for a librarian position was litigated at Merwine v. Board of Trustees for State Institutions of

13 Lester Asheim, Librarians as Professionals, 27 Libr. Trends 225, 228, 231, 232 (1978). The last of his points may be unduly critical. It could be argued that adoption of a stance that, as an ideal, everyone should have access to all materials, or at least to whatever materials a patron inquires about, is in fact the conclusion of our reasoned expertise, and not, as Asheim implies, a failure to be sufficiently prescriptive about what readers should read. We can give them more than they ask for, but we should always strive to give them what they do actually ask for. "The amorality of information provision remains the official professional position, advocated by ALA and many of those who take an interest in this area." Hauptman, supra note 1 , at 3 .

$14 \quad$ Am. Bar Assoc., Dues and Eligibility for Membership in the American Bar Association, at http://www.americanbar.org/membership/dues_eligibility.html; Am. Med. Assoc., FAQ: Who is Eligible to be a Member of the AMA?, http://www.ama-assn.org/ama/pub/membership/ faqs.page.

15 Am. Libr. Assoc., Dues and Member Types, http://www.ala.org/membership/aladues.

16 Am. Assoc. L. Libr., Membership Application, http://www.aallnet.org/Home-pagecontents/Join-benefits/new-member-brochure.pdf.

17 Butler, supra n. 10, at 238.

18 Jean Preer, Library Ethics 30 (2008). 
Higher Learning. ${ }^{19}$ The plaintiff's argument, rejected by the court, was that the requirement constituted sex discrimination.

\begin{abstract}
[Merwine] introduced statistical evidence of the respective percentages of females and males possessing the ALA-MLS degree who applied for professional librarian positions at MSU from 1971 to 1977. Her statistics indicate that 54 percent of the female applicants possessed the ALA-MLS degree while 89 percent of the male applicants possessed the ALA-MLS degree. Thus, she argues, imposition of the degree requirement in 1978 selects out or preempts a much larger percentage of women than men. These statistics form the basis for Merwine's disparate impact claim. ${ }^{20}$
\end{abstract}

Observers at the time expressed concern that the ALA remained uncommitted to the MLS, reflected in an "unwillingness to support that degree legally" in cases such as Merwine. ${ }^{21}$ This ambivalence remains. ${ }^{22}$

Refusal to defend its own educational credential follows on the fact that many ALA members-perhaps as many as one-third of its public librarians $^{23}$-lack this degree, and thus the organization would suffer a significant backlash were it to argue that the MLS was needed to work in libraries or to call oneself a "librarian." Yet such line drawing is precisely what is expected from professions. Librarians thus have only themselves to blame if the "public, and perhaps most librarians as well, is not convinced that the non-professional with experience simply cannot do the job the professionals can do." 24 The public may consider "libraries indispensable, but not librarians." ${ }^{25}$ Librarians, it seems, have not done all they need to receive the social sanction to exercise the special prerogatives characteristic of a profession.

$19 \quad 754$ F.2d 631 (5th Cir. 1985).
$20 \quad$ Id. at 634.
$21 \quad$ Edward G. Holley, The Merwine Case and the MLS: Where Was the ALA?, 15(5) Am. Libr.
327 (May 1984).
$22 \quad$ E.g., the (now former) editor-in-chief of Library Journal has recently gone on record questioning the value of the MLS. Michael Kelley, Editorial: Can We Talk about the MLS?, 138(8) Libr. J. 8 (May 1, 2013) ("can't we have a fraternal, respected, and smart profession without overreliance on an expensive and unnecessarily exclusionary credential?”). Janeen Williams felt the need to respond to critics who doubted the need of the MLS among law librarians. Janeen Williams, The Importance of the MLS Degree for Academic Law Librarians, 38(3) Southeastern L. Libr. 3-4 (Summer 2013). For a detailed argument that "it is time to abandon the MLS project," see Boyd Keith Swigger, The MLS Project: An Assessment after Sixty Years (2010).

$23 \quad$ Swigger, supra n. 22, at 46.

24 Goode, supra n. 11, at 313. Rare are public calls to better police the divide between professional and paraprofessional. For one example, see Ann Puckett, The Egalitarian Fallacy, 81 L. Libr. J. 343 (1989) (arguing that when paraprofessionals are treated as professionals, professionals are treated as paraprofessionals, to the detriment of the library services).

25 Asheim, supra n. 13, at 236 (quoting Thomas Gwinup). 
Were professionals necessarily defined by the structural elements outlined by Greenwood and others, librarianship would indeed present a weak application for membership among the recognized professions. Andrew Abbott, however, has offered a different approach that may yield a more favorable outcome. Abbott argues that the synthetic model of the professions-defining them in isolation by a present-absent trait list-fails because "its basic assumptions have all been overthrown by recent empirical work." ${ }^{26}$ Instead, those elements are common but not necessary means to the end "of creating a coherent occupational group with some control of an abstract expertise," or what he calls a "jurisdiction." 27 Professions rise and fall to the extent they are able to stake out and defend domains, and thus must be studied as parts of an occupational ecology, not as free-standing instantiations of a Platonic essence.

Echoing Greenwood's discussion of the criterion of systematic theory, Abbott's model identifies as one of the hallmarks of a profession an ability to use the discipline's "knowledge system governed by abstractions [to] redefine its problems and tasks [so as to] defend them from interlopers and seize new problems ... Many occupations fight for turf, but only professions expand their cognitive domain by using abstract knowledge to annex new areas, to define them as their own proper work." 28 This approach to identify legitimate professions preserves the core intuitions about which are the prototypical instances, but allows room for other occurrences.

The move of librarianship to grow its jurisdiction from books in libraries to electronic information in multiple settings, as well as to expand its role from the curation of collections for use by others into formal educational duties to train users in navigating the information wilderness, demonstrates the requisite flexibility Abbott expects from professions. He recognizes that librarianship cannot claim exclusive authority of this new expert domain- "No coherent set of people has in fact emerged to take jurisdiction in this area. It continues to be extremely permeable, with most training on the job, most expertise readily commodifiable, and careers following wildly diverging patterns." ${ }^{29}$ But this assessment, which may well have tilted further in librarianship's favor during the quarter century since Abbot wrote, suffices to meet the needs of the present discussion, in which we are justified in treating librarianship, like law, as a profession.

\footnotetext{
26 Andrew Abbott, The System of Professions: An Essay on the Division of Expert Labor 19 (1988). For a detailed overview of the limitations of viewing professions through a trait checklist, see Swigger, supra n. 22, at 109-118.

27 Abbott, supra n. 26, at 154.

$28 \quad I d$. at $9,102$.

29 Id. at 245.
} 


\title{
THE DEEP CHANGES FROM PROFESSIONAL EDUCATION
}

However one chooses the defining characteristics of the professions, all agree that expert, specialized knowledge is involved. Although it is possible to acquire that expertise in a variety of ways, including apprenticeship, our society presently favors formal education for that purpose. While all educational programs strive to impart specific knowledge, professional schools seek also to train and mold future members of its elite fraternity. Something more is required to attain this second, but by some measures no less important, goal.

Toward that end, while most writers focus on the cognitive (theory and authority) and social (sanction and behavioral codes) components of professions, our primary interest lies in the final of Greenwood's attributes, culture. In Greenwood's opinion, "If one were to single out the attribute that most effectively differentiates the professions from other occupations, this is it." 30

As outlined by anthropologist Melford Spiro, to "learn a culture is to acquire its propositions; to become enculturated is, in addition, to 'internalize' them as personal beliefs, that is, as propositions that are thought to be true, proper, or right." 31 Culture provides "the media for 'how to be' and for how to participate as a member in good standing of particular social contexts," 32 including, we may imagine, those labeled "professional." A job is something you do; a profession is, in the end, something you are. ${ }^{33}$

Relevant to the specific context of the professions, culture provides "a basis for the organization of activities, responses, perceptions, and

\footnotetext{
30 Greenwood, supra n. 6, at 52.

31 Melford E. Spiro, Some Reflections on Cultural Determinism and Relativism with Special Reference to Emotion and Reason, in Culture Theory: Essays on Mind, Self, and Emotion 323, 326 (Richard A. Shweder \& Robert A. LeVine, eds., 1984).

32 Urs Fuhrer, Cultivating Minds: Identity as Meaning-Making Practice 82 (Taylor \& Francis, 2003).

33 The following anecdote illustrates the tensions many practitioners feel on the proper role of professional identify in personal life:
}

\begin{abstract}
[Warren] Lupel once represented a real estate lawyer who had gone to prison for fraud. Lupel advised the 75-year-old against seeking reinstatement [to the bar], but the client insisted. He lost. The client came back four years later after a heart transplant; but this time Lupel refused to represent him. "I told him, I didn't get it," says Lupel: "You're 80, you don't have much time left. You're going to pay me $\$ 20,000$ to $\$ 25,000$, and you're not going to win. Why?" He said, "I want on my tombstone that I was a lawyer." I think that's in the mind of a lot of people. They confuse their career with their life.
\end{abstract}

G. M. Filisko, The Rough Road to Redemption, 99(8) ABA J. 46, 51 (August 2013). In light of the present discussion, we can well understand the attitude of the client; it is Lupel's uncomprehending skepticism that signals a departure from the traditional norms of lawyering. 
experiences by the conscious self," 34 a kit of default emotional and behavioral schemes for problems and situations most commonly encountered. Beyond learning special rules, the socialized professional acquires coherent frames through which she interprets the world:

[The] major outcome [of professional socialization] is the holistic acquisition of a status-role. It is the integration of these elements in a role, rather than specific norms, values, habits, etc., that is conveyed in socialization. The status-role as an organized entity is the intended outcome of professional education and accounts for its complexity and duration. ${ }^{35}$

Sherlock and Morris give a sense of how the educational process is structured to achieve these identity-shaping results. They describe seven aspects of the training regime that cumulatively generate the new professional self. For example:

Sequestration is concerned with removing influences which interfere with thorough acquisition of the professional role. These influences are generally of an extracurricular nature, and their removal is accomplished by means of ecological and temporal arrangements which isolate the student from distracting influences and encourage greater attention to studies. By means of this selective patterning of experience, the status of professional student becomes the dominant one; other sources of identity are voluntarily and, in some cases, forcibly subordinated. ${ }^{36}$

Such description links directly with the relevant anthropological literature on transitioning into major life stages. Arnold van Gannep's classic Rites of Passage (1977) describes the phase of liminality, one intended to achieve the same end as that described by Sherlock and Morris: the assumption of a new status, and the creation of a new identity. The need for sequestration helps explain the rise of separate professional schools, when logically the same intellectual content could be acquired through other, more open arrangements that avoid uneconomical redundancies, as when both law and business schools must fund their own versions of the same business law topics. ${ }^{37}$

34 Michelle Z. Rosaldo, Toward an Anthropology of Self and Feeling, in Culture Theory: Essays on Mind, Self, and Emotion 137, 140 (Richard A. Shweder \& Robert A. LeVine, eds., Cambridge University Press, 1984).

35 Sherlock \& Morris, supra n. 8, at 32. The other six institutional processes described by the authors are selection, didactic instruction, apprenticeship instruction, sanctioning, certification, and sponsorship.

$36 \quad I d$. at 34 .

37 While it has been common for business schools to offer their own law courses, law schools are now beginning to include business classes in their curricula. See Law Schools 
Although intended to create a new professional identity, the acquisition of a profession's culture would unsurprisingly exert an influence upon the personal as well. According to Greenwood, for the professional

the absorption in the work is not partial, but complete; it results in a total personal involvement. The work life invades the after-work life, and the sharp demarcation between the work hours and the leisure hours disappears. To the professional person his work becomes his life. ${ }^{38}$

Default perspectives and guidelines for the profession bleed into ordinary contexts, tending toward a mixed, if not fully integrated, perspective. Such integration of work and life comes to be part of the distinctive idea of profession as calling or vocation:

Professionals have traditionally been ascribed vocation as well as a career or a job. Besides earning a living and striving to distinguish themselves in their domain of activity, professionals have been expected to carry out their work as part of a larger collective project. Such a project, like raising a family or serving one's country, is by necessity a long-term, stable commitment. It shapes personal identity by binding the individual's voluntary efforts into a common life and purpose. ${ }^{39}$

An effort to maintain separate value systems becomes increasingly costly with few returns, requiring discordant strategies to negotiate any arising incongruities. ${ }^{40}$ How, for example, "do you help U.S. Steel hold up a pollution

Get Down to Business, Nat'l L. J. (Sept. 23, 2013) ("A growing number of law schools are borrowing a page from the MBA playbook and adding courses intended to give students a foundation in business, in addition to the law").

38 Greenwood, supra n. 6, at 53.

39 William M. Sullivan, Work and Integrity: The Crisis and Promise of Professionalism in America 15 (2nd ed., 2005).

40 Philip J. Osteen, Motivations, Values, and Conflict Resolution: Students' Integration of Personal and Professional Identities, 47 J. Soc. Work Educ. 423, 434 (2011). See also Sandra Janoff, The Influence of Legal Education on Legal Reasoning, 76 Minn. L. Rev. 193, 230 (citing Rand Jack \& Dana C. Jack, Moral Visions and Professional Decisions (1988)):

[Jack and Jack analyzed interview data from eighteen female attorneys.] They found that a majority of their subjects isolated their personal characteristics that were incompatible with the role of a lawyer and guarded against the resulting emotional struggle in one of two ways. Women in one group denied the conflict, subordinating their personal lives to their careers, and, for the most part, disavowing their emotional, relational selves. The women in the other, larger group split their orientations so that their affectionate sides stayed at home and their stoic, detached sides came to the office. The women used these defensive behaviors as protection against the anxiety caused by incompatibility. They inevitably experienced disequilibrium and struggle. 
abatement order during the day, then go home and read your mail from the Sierra Club and tell yourself that you're one human being?" ${ }^{41}$ Legal training may not provide easy answers to such problems, but the present point is that it is the training itself which creates the ethical tensions that confront every conscientious professional. Otherwise, an attorney could simply perform the contracted labor, or not, without feeling any conflicts: While Hitler's plumbers need not have felt any issues when deciding to fix his toilets, his judges should have been less complacent when fixing his courts. ${ }^{42}$

Whatever the explanation, the process of becoming a professional leaves its mark on the individual at the most basic level. By design, no one emerges unchanged. ${ }^{43}$ Over time, one can expect that the individual will either adopt the ethical framework of the chosen professional as an appropriate basis upon which to build a socially productive identity, or evolve some hybrid that seeks a coherent balance between the broad duties of the professional with the values contributed by other important influences, such as religion or ethnic tradition. Professional training intends that students become practitioners who "recognize and manage personal values in a way that allows professional values to guide practice." ${ }^{4}$

This convergence should not be overstated, however, and is certainly neither inevitable nor always uncomplicated. ${ }^{45}$ Yet we must recognize that the cost of maintaining segregated ethical systems can lead to ego depletion with resulting implications for final decisions, ${ }^{46}$ with special issues for attorneys. As Postema argues, integration is to be preferred because otherwise "moral distance" —when the "requirements of professional ethics can sometimes move some distance from the concerns of private or ordinary morality" - can undermine the ability of the attorney to be morally responsible for her actions in a professional role. ${ }^{47}$

\footnotetext{
$41 \quad$ Scott Turow, One L 100 (1977).

42 For an overview on the failure of Nazi Germany's legal professionals to uphold the principles of justice, see Hitler's Courts: Betrayal of the Rule of Law in Nazi Germany (Touro College Jacob D. Fuchsberg Law Center, 2006).

43 Turow, supra n. 41, at 10 ("And thus it is during the first year that many law students come to feel, sometimes with deep regret, that they are becoming persons strangely different from the ones who arrived at law school in the fall").

44 Council on Soc. Work Educ., Educational Policy and Accreditation Standards (rev. March 27, 2010), http://www.cswe.org/File.aspx?id=13780.

45 E.g., Constance A. Nathanson \& Marshall H. Becker, Professional Norms, Personal Attitudes, and Medical Practice: The Case of Abortion, 22(3) J. Health \& Soc. Behav. 198 (1981). 46 Daniel Kahneman, Thinking Fast and Slow 31-49 (2011).

47 Gerald J. Postema, Moral Responsibility in Professional Ethics, in Profits and Professions 37, 38-39 (Wade L. Robison, Michael S. Pritchard, \& Joseph Ellin, eds., 1983) ("I contend that a sense of responsibility and sound practical judgment depend not only the quality of one's professional training, but also on one's ability to draw on the resources of a broader moral experience. This, in turn, requires that one seek to achieve a fully integrated moral personality").
} 
Important consequences follow from this description. Successful inculcation into a profession's "tool kit" 48 entails a change of the aspirant's interpretive schemata. Through rigorous training and conscious role modeling, the student's background assumptions with which she approaches not only the problems within the profession's jurisdiction, but situations more broadly, gradually alter. Wagner Thielens provides longitudinal data that show the changing attitudes of entering law students toward the acceptability of contingency fees. Although positions were initially linked to demographic and other extraneous variables, by graduation those relationships had disappeared. Thielens concludes that these "dissolutions of the individual links, occurring together, amounted together to the partial dissolution of a segment of entrants' value system" under the influence of law school socialization. ${ }^{49}$

Educationally induced perspectives can become a default dispositional posture that impacts the whole of the practitioner's life. Debra Schleef illustrates this tendency for professional students to begin using their new "language outside of school settings, even in reference to their personal lives" by telling how "one [MBA student] used 'bringing in a deal' in reference to his engagement." 50 The ways of being a good professional, in other words, after taking up residence within the deep levels of the individual psyche, can exert an organizing force upon how she views the world more broadly.

If these powerful effects are the routine outcome of the process of professional socialization, what can we expect from those who submit to being similarly deconstructed not once, but multiple times? Is an individual equally susceptible to repeated immersion in this experience of remaking? That later professional instruction can completely undo or rewrite the first process is belied by the description of the deep levels at which this process occurs. The drive toward holistic life integration similarly suggests that the two identities and ways of living cannot be easily compartmentalized.

The most parsimonious hypothesis that respects the literature on professional education suggests that the first immersion dominates, with later training gaining such foothold as it can where it does not fundamentally challenge or contradict the first. In other words, the first experience of professional training will form the basis of personal identity and provide the primary default position from which the student encounters and interprets the world, including later professional education.

We find supportive evidence of this claim in research by Schleef on the process of "anticipatory socialization." According to this model, enculturation

\footnotetext{
48 Debra J. Schleef, Managing Elites: Professional Socialization in Law and Business Schools 204-210 (2006).

49 Wagner Thielens, The Socialization of Law Students: A Case Study in Three Parts, Ph.D. dissertation, Columbia University 242 (1965).

50 Schleef, supra n. 48, at 102.
} 
occurs when new members begin to consciously model themselves on the perceived qualities of those they aspire to join in order to "find readier acceptance by that group and make an easier adjustment to it." ${ }^{51}$ Among the factors that can interfere with this process, however, are "too much knowledge [which] can potentially create resistance to dominant messages about jobs and merit." ${ }^{12}$ Unsurprisingly, older students can be expected to have a different educational experience than those who arrive at professional schools lacking conflicting beliefs about the process: "Given prior socialization in work settings, such students did not expect to be caught off guard by new experiences." 53

Having just the right amount of exposure to this knowledge prior to school is important. Students who possessed less cultural capital upon arrival never acquired a full understanding of professional ideology in a way that made mainstream jobs attractive and accessible. Students who were too cynical too early, and who had already formulated ideas about how law or business ought to be practiced, were also less susceptible to professional socialization. Having too much cultural capital, then, provided diminishing returns to such students. ${ }^{54}$

In line with Schleef's observations, then, those who arrive at one professional school having already completed another can be anticipated to not be fully "susceptible to professional socialization," resulting in different attitudes toward the ordinary preferences students are expected to absorb.

If the formative values for lawyers and librarians diverge on points of interest, the sequence of professional indoctrination would consequently generate subtly yet distinctly different types of law librarians. The next section separately describes the normative postures of each profession; the subsequent discussion returns to the problem of how these disparate identities might be expected to interact.

\section{DISTINCTIVE OUTCOMES OF PROFESSIONAL EDUCATION FOR LAWYERS AND LIBRARIANS}

The previous section argued that professions are distinctive from other occupations in that they instill a coherent perspective-combining theory, technique, and ethics - that not only serves as the basis for practice but also

\footnotetext{
51 Robert K. Merton and Alice S. Kitt, Contributions to the Theory of Reference Group Behavior, in Continuities in Social Research: Studies in the Scope and Method of "The American Soldier" 40, 87 (Thomas K. Merton, ed., 1950).

52 Schleef, supra n. 48, at 50.

$53 \quad I d$. at 63.

$54 \quad I d$. at 71
} 
extends to influence the member's private identity and default interpretive schemata. If we accept that each profession has a unique jurisdiction defended with a proprietary abstract theory, it follows that each profession will also pursue those projects by means of its specific constellation of cultural elements. This section briefly sketches the prototypical emphases and intended outcomes of the trainings for law and librarianship.

\section{"Think Like a Lawyer"}

If professions involve changes to self-perceptions, law is one of the few that specifically singles out this facet of its educational process for discussion. Learning "to think like a lawyer" is a clichéd goal of American legal education, often becoming a higher priority than training in any actual practical skills. ${ }^{55}$ The meaning of the mantra, however, is at best vague.

James Elkins describes the goal to "think like a lawyer" as referring to the distinct way of reasoning that puts "the rhetoric of law to work to compartmentalize legal and moral discourse." 56 This ideal is no accident, but was proposed by one of the formative figures of legal thought, Oliver Wendell Holmes, in his classic essay, The Path of the Law:

For my own part, I often doubt whether it would not be a gain if every word of moral significance could be banished from the law altogether, and other words adopted which should convey legal ideas uncolored by anything outside the law ... [By] ridding ourselves of an unnecessary confusion we should gain very much in the clearness of our thought. ${ }^{57}$

Severing the legal from the irrelevantly moral is achieved largely through the case study method. Through this pedagogical technique, stories of real lives are distilled into discrete facts from which those that are legally significant are noticed while all others are dismissed.

Learning to think like a lawyer via the case method, according to Elkins, ultimately "makes personal spheres of caring irrelevant," and, significantly for our purposes, this way of thinking "becomes a worldview." 58 "Thinking like a lawyer" leads to "a legal world view that crowds out other perspectives and

55 David T. ButleRitchie, Situating "Thinking Like a Lawyer" within Legal Pedagogy, 50 Clev. St. L. Rev. 29, 30 (2002) ("it may be accurately said that 'thinking like a lawyer' is a simulacrum for competing notions of what a legal education is, or should be, all about").

56 James R. Elkins, Thinking Like a Lawyer: Second Thoughts, 47 Mercer L. Rev. 511, 517 (1995).

57 Oliver Wendell Holmes, The Path of the Law, 10 Harv. L. Rev. 457, 464 (1897).

58 Elkins, supra n. 56, at 526, 523. 
ways of speaking, seeing, experiencing, and understanding the world. The ordinary progress of learning legal thinking requires a psychic numbing." 59

The formative influences of the case method are indeed potent. Devised by Christopher Columbus Langdell in order to advance the study of law as a science, the associated casebooks compile edited appellate opinions on a legal topic, from which students are challenged via Socratic questioning to identify the true rule of law toward which these holdings aim with evercloser approximations. Although the merits of this classroom procedure have recently been challenged, appellate cases remain the primary teaching tool, although today they may as often be read "to study legal reasoning and legal argument than to search for substantive rules." 60

Other writers have suggested other ways in which education for legal work can leave traces on the student's mundane perceptions:

[Morris L.] Ernst, for example, has stated that law school's emphasis on the case system encourages an "emotional preference for [ ] status quo and stare decisis." [William] Forrester writes that the function of law school is to teach students the relativity of all viewpoints and the "nonsanctity of anything"; the layman sees facts as unilateral, but the lawyer cannot. [Julius] Cohen describes "looking backward" as a badge of the profession." 61

Another way in which the traditional elements of the first-year curriculum influence moral perceptions involves the need to learn to argue both sides of any issue with equal ease, as expected during moot court and legal writing courses. ${ }^{62}$ After relentless drilling that he should be able to argue zealously whatever side of an argument that the client requires, an attorney, believing that there exist two sides to every argument, may find it challenging to adopt any uncompromisable truths to which he should be committed.

59 Id. at 529. The claim that lawyers predominantly favor logical decision making over subjective approaches receives support from the Myers-Briggs Type Indicator. Larry Richard reports that while " 60 percent of all men in this country prefer thinking over feeling ... fully 81 percent of male lawyers preferred thinking." Larry Richard, The Lawyer Types, 79(7) ABA J. 74, 76 (July 1993). The corresponding rates for women are 35 and 66 percent respectively. Id. Similarly, law students who fall into the Feeling type "dropped out of law school [more] than did the Thinking types, suggesting that Feeling may be more incompatible with the study of law." Susan Daicoff, Lawyer Know Thyself: A Review of Empirical Research on Attorney Attributes Bearing on Professionalism, 46 Amer. U. L. Rev. 1337, 1366 (1997). Daicoff considers this divergence from the general population "Perhaps the most consistent finding among all studies done of lawyer characteristics." Id. at 1392.

$60 \quad$ Philip C. Kissam, The Disciplines of Law Schools 38 (2003).

61 Thielens, supra n. 49, at 146 (quoting Morris L. Ernst, The Legal Profession: 50-Year Stocktaking: Too Little Progress, 5 J. Pub. L. 283, 286 (1956), Julius Cohen, Comments, 5 J. Pub. L. 291 (1955), and William Ray Forrester, Comments, 5 J. Pub. L. 295, 297 (1955)).

62 E.g., Turow, supra n. 41, at 163 ("Like a good lawyer, the student is expected to be able to argue both sides of the issue"). 
Self-reports from law students support this lesson that "learning there were no right answers, or that any answer could be right, affected moral reasoning." 63

This outcome is just what Plato feared when he complained of the Sophists that they believed in no higher values but only in using their rhetorical skills to achieve the ends of whomever was paying their fees. ${ }^{64}$ The ethical implications of this skill continue to worry others. Mark Sargent finds that "as professionals trained to make 'arguments' on either side of an issue, [lawyers] can allow a high degree of rationalization of their complicity in conduct that is ultimately not in their corporate client's interest, certainly not in the public interest and often immoral if not illegal." 65 James Taylor claims that this "practice in arguing both sides of a case produced general effects: all standards become less firm; and some second-year students said they no longer had strong convictions about anything." 66

A final element in which "thinking like a lawyer" can differ from other ways of encountering the world results from the intersection of the uniquely American emphasis on the adversarial legal tradition, with its equally schooled value of the zealous defense. The prototypical adversarial system of law envisions a contest of formal equals before an impartial judge and a verdict-rendering jury; this system is often viewed not as a means to justice, but rather as the very definition of justice itself, without which justice has been denied. ${ }^{67}$ The contrasting inquisitorial systems seek to uncover the true facts of the matter. These approaches "are not alternative ways to serve the same process [of assigning criminal liability]. They represent basically different views of what the purpose of law is, and even of what is the purpose of the state." 68

\footnotetext{
63 Schleef, supra n. 48, at 99.

64 Terry Penner, Socrates and the Early Dialogues, in The Cambridge Companion to Plato 121, 137 (Richard Kraut, ed., 1992):
}

\begin{abstract}
For Socrates, as for Plato, there is no doubt that the main philosophical enemy is the sophists and rhetoricians whose form of education is one that offers neutral techniques for "getting on" in private and political life-neutral in that they are indifferent to any good in human life other than what the individual chooses to think is good-the individual's "values" (as we say). The sophists and rhetoricians purport to put persuasive means in their students' hands to achieve whatever goals "seem best" to them, without raising any questions about what people take to be their ends.
\end{abstract}

\footnotetext{
65 Mark A. Sargent, Lawyers in the Moral Maze, 49 Vill. L. Rev. 867, 880 (2004).

66 James B. Taylor, Law School Stress and the "Déformation Professionelle", 27 J. Legal Educ. 251, 258 (1975-76).

67 Abbott, supra n. 26, at 185.

68 Hans F. M. Crombag, Adversarial or Inquisitorial: Do We Have a Choice?, in Adversarial versus Inquisitorial Justice 21, 22 (2003).
} 
Robert Kagan explains the rise of American adversarial legalism as the outcome of two primary factors:

first, a political culture (or set of popular political attitudes) that expects and demands comprehensive governmental protections from serious harm, injustice, and environmental dangers-and hence a powerful, activist government-and, second, a set of governmental structures that reflect mistrust of concentrated power and hence that limit and fragment political and governmental authority. ${ }^{69}$

"American lawyers and law professors ... have created and defended a body of legal ethics that exalts adversarial legalism. In the United States lawyers' codes of ethics endorse zealous advocacy of clients' causes, short of dishonesty, but without regard to the interests of justice in the particular case or broader societal concerns." 70

Accordingly, the Preamble to the profession's code of ethics states that attorneys must argue their client's side with vigor uncommon outside this adversarial legal tradition:

As advisor, a lawyer provides a client with an informed understanding of the client's legal rights and obligations and explains their practical implications. As advocate, a lawyer zealously asserts the client's position under the rules of the adversary system. As negotiator, a lawyer seeks a result advantageous to the client but consistent with requirements of honest dealings with others. As an evaluator, a lawyer acts by examining a client's legal affairs and reporting about them to the client or to others. ${ }^{71}$

In addition to these duties of client representation, the lawyer is also charged with responsibilities as "an officer of the legal system and a public citizen having special responsibility for the quality of justice." ${ }^{, 2}$ These responsibilities are anticipated, according to the Rules, to be "usually harmonious."73 While that might lead some to believe that the three prongs of lawyerly duty are equivalently weighted, a closer reading understands the duties of client representation as the principle driver of proper professional conduct. If the "zealous" advocacy of the client is executed properly, the remaining pieces fall into place:

\footnotetext{
69 Robert A. Kagan, Adversarial Legalism: The American Way of Law 15 (2001). Id. at 55 .

Am. Bar Assoc., Model Rules of Professional Conduct Preamble Sec. 2, http://www. americanbar.org/groups/professional_responsibility/publications/model_rules_of _professional_conduct/model_rules_of_professional_conduct_preamble_scope.html.

$72 \quad$ Id. at Preamble Sec. 1.

73 Id. at Preamble Sec. 8
} 
Thus, when an opposing party is well represented, a lawyer can be a zealous advocate on behalf of a client and at the same time assume that justice is being done. So also, a lawyer can be sure that preserving client confidences ordinarily serves the public interest because people are more likely to seek legal advice, and thereby heed their legal obligations, when they know their communications will be private. ${ }^{74}$

Client-based conflict resolution thus serves as the formative lens of lawyerly ethical evaluation and the standard to achieve societal justice. This approach prioritizes the present moment's issues over any long-term ramifications, as Kagan suggests. Short only illegal acts, attorneys owe a duty of zealous representation. That obligation precludes weighing any fallout should they win their cases on the grounds argued, even when that means a guilty person goes free on a technicality in all likelihood to commit further crimes, or whether the argument will open a Pandora's box of unintended consequences. In the profession's view, constructing a fair system depends on this exclusive focus to resolve the conflict immediately at hand, forbidding any thought of sacrificing the present client's interests for the sake of larger societal issues. Those long-range concerns will rather be better served through the energetic presentation of this client's case. This way of thinking can be foreign to the uninitiated, who may trust less in the intrinsically superior moral value of procedure over outcome.

"Legal professionals do, in fact, have a distinct way of thinking about the world" into which it is the challenge for law professors to initiate the new law student. ${ }^{75}$ As reviewed in the preceding, the varying components of this viewpoint include elevating rational thinking at the expense of emotional standards of evaluation, favoring a backward-looking status quo, and believing that broader social goods are best achieved not directly but through zealous pursuit of the immediate individual goals.

Students receiving this instruction are often fully aware of the changes occurring within them, but their desire to succeed in the profession compels either a full submission or an ongoing tension between the competing worldviews:

As a law student, you can always dissociate yourself knowing that what you are doing is not for real and you are just doing what you have to in order to get through school. As a lawyer, the problems become real, but you have become so used to dissociating yourself with your moral/ethical self that you can no longer distinguish the real you from the lawyer you. It is frightening. ${ }^{76}$

\footnotetext{
$74 \quad I d$.

75 ButleRitchie, supra n. 55, at 32.

76 Elkins, supra n. 56, at 528-529.
} 


\section{The Librarian Personality}

Librarian education lacks a recognized maxim of its intended goal akin to law's learning to "think like a lawyer." Lacking a self-assigned objective, we must unpack the impact of professional socialization upon library school students through a different point of entry. This section begins by sketching the collective images of the typical librarian personality. With a coherent portrait in hand, it then attempts to discern to what extent these perceptions arise out of the consistent qualities of those drawn to the profession, and, where possible, to what extent they represent the outcome of the changes wrought by professional socialization.

\section{THE LibraRIAN STEREOTYPE}

In American society there exists a well-defined stereotype of the kind of person who becomes a librarian: "a fussy old woman of either sex, myopic and repressed, brandishing or perhaps cowering behind a date-stamp and surrounded by an array of notices which forbid virtually every human activity." 77 Even when employed to portray subversive empowerment, as in Haunted Love's 2006 music video Librarian, the fundamental vocabulary to construct the social category remains consistent.

The primary questions for present purposes are: (1) Is this description of the librarian personality based on an empirical reality; and (2) to the extent it is an accurate sketch, is this because these types of persons are drawn to librarianship, or does the process of becoming a librarian stamp an originally heterogeneous population with this unifying character?

Robert Douglass made the first significant attempt to address the first question when he tested the following hypotheses:

Hypothesis 1.-The librarian is more orderly, meticulous, neat, and compulsive in behavior than people in general.

Hypothesis 2.-The librarian is more conscientious, scrupulous, and conforming, and less innovative and creative than people in general.

Hypothesis 3.-The librarian is more deferential, submissive, and respectful of authority than people in general.

Hypothesis 4.-The librarian is more self-contained, self-sufficient, preoccupied with subjective feelings, introspective, introvertive, and non-social than people in general.

Hypothesis 5.-The librarian is more anxious and less self-confident than people in general.

Hypothesis 6.-The librarian is more neurotic than people in general.

77 Penny Cowell, Not All in the Mind: The Virile Profession, 29(3) Libr. Rev. 167, 167 (1980). 
Hypothesis 7.- The male librarian is more feminine in his interests than men in general.

Hypothesis 8.-The value system of the librarian is characterized by over-emphasis on the theoretical and the aesthetic values, and by underemphasis on the economic and political values. ${ }^{78}$

Douglass administered a variety of instruments, including the Minnesota Multiphasic Personality Inventory (MMPI) and the Allport-Vernon Study of Values, to 525 library school students in 1947-1948, and another 20 males in 1955-1957. The data supported hypotheses 1, 2, 4, and 7. Library students were indeed more orderly, meticulous, neat, and compulsive, more conscientious, scrupulous, and conforming, but less innovative and creative, more self-contained, self-sufficient, preoccupied with subjective feelings, introspective, introverted, and non-social when compared with normed values for the general population. Likewise, the interests of male librarians were more "feminine" than those of men in general.

Hypothesis 8 ("The value system of the librarian is characterized by over-emphasis on the theoretical and the aesthetic values, and by underemphasis on the economic and political values") applied clearly to the males in his sample, but only the latter statement predicting a lack of interest in political and economic issues appeared to describe the female library school students. While Hypothesis 3 "was not confirmed by the three measures used in testing," Douglass believed that "results from other measures, particularly those used in testing Hypothesis 2, provided evidence in support" that the librarian is more deferential, submissive, and respectful of authority. ${ }^{79}$ Only hypotheses 5 and 6 were rejected by Douglass. The librarian is not more anxious or neurotic, an outcome he attributes to the energy librarians expend to bring order to their environments, thereby allowing them to channel and mitigate those tendencies through productive work.

Douglass's work concludes that the stereotype of the librarian appears to have a basis in the personalities of real librarians. Allaying concerns that his result applies only to an earlier age is the fact that the conclusion has stood the test of replication. Given the crudeness of Douglass's methodology, that subsequent studies have confirmed his result is all the more impressive. In his 1984 review of the subsequent published studies of librarian personality, John Agada finds that "In general, their results were consistent with a normal personality profile and congruent with the stereotypical image of librarians," ${ }^{80}$ although not everyone agrees. ${ }^{81}$ Some have suggested that as

\footnotetext{
78 Robert R. Douglass, The Personality of the Librarian, Ph.D. dissertation, University of Chicago Graduate Library School 29 (1957).

$79 \quad$ Id . at 120 .

80 John Agada, Studies of the Personality of Librarians, 20(2) Drexel Libr. Q. 24,38 (1984).

81 See David P. Fisher, Is the Librarian a Distinct Personality Type?, $20 \mathrm{~J}$. Libr. Info. Sci. 36, 44 (1988) ("it is not possible to state that the librarian is a distinct personality type").
} 
the profession becomes less "bookish" and more computer-based, the modal personality of the librarian will also undergo a corresponding transition, but the data on this point have been thus far equivocal. ${ }^{82}$

\section{TyPe GENESIS}

While the stereotype of the librarian will not describe every member of the profession, and may experience drift over time as social perceptions and job requirements change, it has been sufficiently accurate for sufficiently long to raise the second question: whether this outcome is a convergence of two independent variables - a stable personality type being drawn to an accepting work environment - or whether one is dependent on the other. To what extent is the modal librarian personality the consequence of librarian education and experience, and not its precursor?

Whatever the merits of Douglass's landmark study, it does not address this latter question. Identifying three logical relationships between personality clusters and occupational groups-the occupation attracts people of a certain type, it "may actually affect personality structure," or some combination of the $\mathrm{two}^{83}$ - he explicitly limits his investigation only to the first. We must look elsewhere if we wish to discover whether library education creates the kinds of people that conform to its popular stereotype.

To draw the desired distinctions, we require longitudinal studies on library students along the lines that Thielens provides for law students. The only methodologically relevant study identified is also one of the very few that directly compare librarians and lawyers. Two cohorts of Nigerian law and library students were evaluated upon entrance and graduation on their levels of assertiveness. Their respective faculties described the preferred personality traits for effective practice:

- For the library profession—being polite, pleasant, friendly, patient, cooperative, empathic, and persevering ...

- For the law profession-being assertive, persuasive, logical, acquisitive, and enterprising. ${ }^{84}$

Although in both groups the library students began their educations with more assertive personalities than the entering law students, by graduation the relationship had changed dramatically. Both groups had come to emulate

\footnotetext{
82 See, e.g., Anne Goulding, Beth Bromham, Stuart Hannabuss, \& Duncan Cramer, Professional Characters: The Personality of the Future Information Workforce, 18 Educ. for Info. 7 (2000).

83 Douglass, supra n. 78, at 26.

84 John Agada, The Librarian Personality and Professional Socialization: A Longitudinal Study of Library School Students in Nigeria, 35 J. Educ. Libr. \& Info. Sci. 83, 90-91 (1994).
} 
the ideal personality for their respective professions, and in this instance at least that outcome can clearly be attributed to the effects of their training curricula. ${ }^{85}$ A later study reached a similar result using an American sample comparing library and counseling students. ${ }^{86}$

Here we have on-point data supporting the socializing impact of library school education. Originally assertive enrollees reshaped themselves to conform with the prevailing librarian stereotype to become, in Douglass's terms, deferential and submissive. If we grant that library school education exerts a formative influence to replicate the elements of the librarian stereotype, we can briefly consider why this might be the case.

Thad Dickinson has suggested that the foundation for this modal professional personality emerged at a time when librarians "were held financially accountable for missing books, ... were often responsible for collecting fines and dues, and ... were most likely already over-burdened professors." 87 In such an environment these quirks of personality would have been reasonable adaptations, and prudent models to emulate. In that context the standard librarian demeanor would have been a learned style responding to the needs of managing those early libraries.

The practical need for such a defensive posture to guard the collection is no longer usual, raising the further question as to why it has persisted to the present day. One possibility is that, even assuming contemporary librarians are themselves ready to surrender the stereotype, those who make the hiring choices for upper level positions-for example, deans, faculty, boards, and trustees - are often professional outsiders who may be more susceptible to the culturally reinforced image. As Daniel Kahneman explains, professional stereotypes are "System 1" heuristics that we are inclined to treat as true unless we exert the deliberate effort to engage "System 2" conscious reasoning as a corrective. ${ }^{88}$ That bias may indirectly motivate each new generation to adopt those mannerisms in order to succeed in the marketplace even though they no longer serve a direct function to perform necessary tasks. Seeing the behaviors modeled by the successful incumbents of the profession's upper echelon, new aspirants adopt the norms as their own.

When the complete account is told, a conservative expectation is that the true circumstances will best fit the third of Douglass's theoretical positions: The librarian personality stereotype will likely prove to be a combination

\footnotetext{
85 Data on American law students reporting a similar perceived increase in aggression due to law school tensions support the generalizability of these Nigerian findings. See Robert Stevens, Law Schools and Law Students, 59 Va. L. Rev. 551, 677-678 (1973) ("Those persons who remained at a high level of tension were more likely to perceive themselves as becoming more aggressive").

86 John Agada \& Kenneth Weaver, Empathy, Assertiveness and Professional Socialization in Library Education, 27(2) J. Libr. \& Info. Sci. 1 (1997).

87 Thad E. Dickinson, Looking at the Male Librarian Stereotype, 37 Ref. Libr. 97, 101 (2003).

88 Kahneman, supra n. 46, at 3-30.
} 
of initial predispositions shaped by the formative socializing experiences of library school. This understanding of the educational impact follows upon the expectations of those closest to the process. Like attorneys, library professionals "share a worldview shaped by their common professional training and experience. Moving from practical training to the academy, future professionals learn to view problems through the particular lens of shared expertise and values." ${ }^{89}$ Attempts to summarize the content of these shared values imbued during library school would include the following:

\begin{abstract}
Many librarians would agree with the following belief statement (aka articles of the Library Faith): that the act of silent reading of nonfiction as well as fiction is desirable; libraries should avoid censorship and support intellectual freedom by offering a balanced or unbiased collection of authoritative or at least credible materials, be public, free of direct use fees; furthermore, these cultural nonprofits are good or desirable while large, for-profit companies are bad (if not, lazy or even evil)—or simply put, many librarians would respect intellectual property rights (but support the notion of fair use within the bundle of copyrights), yet oppose the increasing "commodification" of information. ${ }^{90}$
\end{abstract}

\title{
Direct Comparisons
}

The descriptions of lawyers and librarians offered in the preceding, developed in isolation from one another, may impress the reader as starkly divergent. This impression may, however, owe as much to the manner in which the story has been told as to any actual differences. Unfortunately, the two professions have rarely been directly compared; this section summarizes what little information exists to further support the conclusion that librarians and lawyers tend toward significantly divergent qualities and values. Those variations open the door to inquire what happens when the roles exist in the same individual.

In addition to the Agada study described in the previous section, which contrasted the assertiveness of students of law and librarianship, only three other studies were identified that sampled both lawyers and librarians. The first compared 108 female freshmen on scores from the Allport-Vernon Study of Values and the Strong Vocational Interest Blank for Women. The authors found that while the Lawyer profile "is positively related to economic and political values, and negatively to aesthetic and religious values ...; Librarian

\footnotetext{
89 Preer, supra n. 18, at 3.

90 John V. Richardson, Jr., Library Science in the United States: Early History, in Encyclopedia of Library and Information Sciences 3440, 3443 (3d ed., 2010).
} 
is positively related to aesthetic values, and negatively to social values." 91 The two groups' aesthetic values, in other words, as measured by these instruments, are significantly and oppositely correlated, and students with vocational aptitudes for law and librarianship share no value dimension in common. A second study looked at handedness among nine professional groups, and found that:

Architects and lawyers had the most lefthanded average laterality scores. Orthopedic surgeons, mathematicians, and librarians had the most righthanded average laterality scores. Psychiatrists and lawyers had the most ambilateral laterality scores, mathematicians and librarians the least. $^{92}$

Although it is beyond the scope of this article to review the research on intellectual and personality correlates of handedness, the significance of this difference may relate to patterns of cognitive development:

[We] find consistent evidence that left-handed children perform worse than right-handed children in all areas of development with the exception of reading. Quantitatively, the differences in development are important, with left-handed children scoring about $6 \%$ of a standard deviation lower in vocabulary tests, $7 \%$ lower in mathematics tests and $8 \%$ lower in comprehension tests than their right-handed siblings. No significant difference, however was found for reading tests. ${ }^{93}$

The authors attribute such results to "a difference in brain functioning" rather than the social environment. ${ }^{94}$

More on point, Kaler et al. studied perceptions of twelve personality traits for fourteen occupations, including lawyers and librarians. On the two-dimension solution, the horizontal axis was interpreted as achievement versus helping orientation, and at "one extreme were business executive, lawyer, police and athlete, and at the other extreme were librarian, clergy, nurse and homemaker." 95 While the first group was "perceived as being more masculine, cold, competitive, concerned with self and as leaders ... [the latter was] generally seen as more feminine, generous, honest and idealistic."

91 Elizabeth Duffy \& W. J. E. Crissy, Evaluative Attitudes as Related to Vocational Interests and Academic Achievement, 35(2) J. Abnormal \& Soc. Psychol. 226, 231 (1940).

92 Steven C. Schacter \& Bernard J. Ransil, Handedness Distribution in Nine Professional Groups, 82 Perceptual \& Motor Skills 51 (1996).

93 David W. Johnston, Michael E.R. Nicholls, Manisha Shah \& Michael A. Shields, Handedness, Health and Cognitive Development: Evidence from Children in the National Longitudinal Survey of Youth, 176 J. Royal Statistical Soc. 1, 16-17 (2013).

$94 \quad$ Id.

95 Sandra R. Kaler, David A. Levy \& Matthew Schall, Stereotypes of Professional Roles, 21(2) Image: J. Nursing Scholarship 85, 87 (1989). 
Overall, lawyers scored highest among all groups on realism, greediness, dishonesty, leadership and logic, while librarians earned extreme marks on introversion, cooperation, and relaxation. ${ }^{96}$

Although few, these empirically observed differences between librarians and lawyers give unanimous support to the general claim that the modal qualities of each professional group are not merely different from the other, but often mutually exclusive. ${ }^{97}$ More side-by-side comparisons, however, are definitely in order.

The foregoing facts generate the following conclusions and predictions:

1. Professional development is objectively real and significantly different from simple occupational job training.

2. One outcome of professional education is the individual's enculturation into the values and viewpoints needed to successfully perform in the practice. Once acquired, these interpretive schemata and postures, due to processes of psychological economy, come to influence personal defaults as well.

3. Given the fundamental levels at which professional enculturation operates, when an individual undergoes professional education more than once, the first training regime will typically have the more dominant impact on the general personality. ${ }^{98}$

96 Id. at 88, Table 1. See also Mary Jane Scherdin \& Anne K. Beaubien, Shattering Our Stereotype: Librarians' New Image, 120(12) Libr. J. 35, 36 (1995) ("Those with extraverted, sensing, and perceiving preferences pop up least in the library profession").

97 A fifth study directly comparing law librarians to lawyers also supports this conclusion. Unfortunately, other than mentions in other documents, the original report could not be obtained, even from the publisher. In the interests of comprehensive treatment, the citation reads as follows:

"Strange Bedfellows? How Myers-Briggs can Help Lawyers and Librarians work Together" by Maureen Provost in Update: The Lexis Newsletter for Private

Law Librarians, v.3:6, p.1 [1992] ("Lawyers and librarians are fundamentally different in the ways they focus their attention, absorb and process information, make decisions and interact with others").

Marie Wallace, Guide on the Side-TRIPLL: Reflections on the Origins of a Unique Series of Conferences, LLRX (June 28, 2002), http://www.llrx.com/columns/guide65.htm.

98 A possible refinement of this claim, unexplored here, is that given the uneven historical development of the recognized professions, competition among professional training within the psychology of the individual is not a battle of equals; the more mature professions, like law, will exert a disproportionate influence over the lesser developed ones, such as librarianship. See, e.g., Samuel Rothstein, Why People Really Hate Library Schools, Libr. J. 41, 42 (1985) (discussing the view that, due to its brevity, library education programs are "just too brief to allow time for adequate 'socialization'"). This suggestion follows from the line 
4. Because each professional culture is specially adapted to apply its unique techniques within a defined context, professions may conflict on specific values, which can lead to divergent solution strategies and outcome preferences for shared problems.

The following section seeks to provide data relevant to the interpretation of this last hypothesis.

\section{EMPIRICAL ASSESSMENT OF PRACTICAL SIGNIFICANCE}

Members of lawyering and librarianship professions are perceived to be different types of persons; the available empirical evidence suggests that these perceptions reflect an underlying reality; and finally, grounds exist to attribute such differences to the respective programs of professional education. The foregoing also supports, given the nature of professional education, an expectation that the sequence of exposure yields different results. The net outcome of the librarian going to law school will not be identical to the lawyer attending library school. On this cumulative foundation we may now propose an example of how differences between these two groups might impact the ordinary practice of librarianship.

Wiegand offers one testable conclusion when he suggests that "Unlike the professions of medicine or law, the library profession is oriented toward a corporate rather than a competitive environment, and the communal nature of the institution in which librarians work is reflected throughout the curricula that socialize library students." 99 Our first endeavor, however, develops the earlier emphasis on ethical principles unique to each profession.

As described by Greenwood, a profession's ethical code can provide insight into what it sees as its highest priorities and its normal views on relationships to others and to society. Because these rules are designed to promote the specialized goals of each discipline, the codes-both explicit

of reasoning that because law school is longer than library school, and law is socially more prestigious than librarianship, learning to "think like a lawyer" will tend to dominate the psychology of the student more than would be expected from order of acquisition alone. In other words, while the sequence-based difference investigated here are important withingroup factors, it remains an empirical question whether dual-degreed law librarians are not more similar to one another than they are to librarians without legal training. Of course, a thorough consideration of the problem will also take into account any diminished stature of the legal profession: "[Deborah] Rhode makes a strong case that law has been losing public confidence largely because as a profession it fails to live up to its fiduciary responsibility to make the system of justice function well and equitably." Sullivan, supra n. 39, at 62 .

99 Wayne A. Wiegand, The Socialization of Library and Information Science Students: Reflections on a Century of Formal Education for Librarianship, 34 Libr. Trends 383, 395 (1986). 
and implied-can be anticipated to differ from one another in characteristic ways, and at points even conflict.

This section finds one example of such an ethically based divergence between law and librarianship in their discordant views on the time span over which their professional obligations are most active. Although law is typically concerned with resolving immediate disputes of specific clients, librarianship has at its core long-term concerns such as the preservation of materials. When embedded in general professional activities, these divergent temporal horizons can cause lawyers and librarians to weigh differently competing interests in areas of common concern.

\section{Divergent Temporal Perspectives}

As described earlier, the U.S. adversarial system of law fosters an environment of legal action that directs greater attention to short-term disputes. The instant of the present problem is the only moment that is legally significant. While different legal contexts might encourage a view of the "big picture," the fact is that lawyers represent their clients, not society, and the Rules specifically hold that society is best served by the vigorous defense of individual clients-a legal analogy, perhaps, to Adam Smith's "invisible hand" of economics, which argues that the most efficient system emerges when everyone pursues their own private interests. ${ }^{100}$ Attorneys are not to look ahead and weigh the longterm consequences of a particular argument that may benefit their client but prove detrimental to the community.

This temporal narrowness applies in both directions. Not only are law students encouraged not to look beyond the present problem toward possible implications of their current actions, but, according to some commentators, they lack both skills and motivation to put those same actions into the context of the past out of which their legal rules arose: "It is not merely ... that law students lack historical context: it is that they do not want to know about it. Indeed, law students positively refuse to seek out historical context."101 Routine omission of deep treatment of issues in student writing

\footnotetext{
100 Adam Smith, The Wealth of Nations, Book IV, chapter II, 349 (Amsterdam: MetaLibri, 2007), http://www.ibiblio.org/ml/libri/s/SmithA_WealthNations_p.pdf ("By preferring the support of domestic to that of foreign industry, he intends only his own security; and by directing that industry in such a manner as its produce may be of the greatest value, he intends only his own gain, and he is in this, as in many other cases, led by an invisible hand to promote an end which was no part of his intention").

101 Robert M. Jarvis, Phyllis G. Coleman, \& Gail Levin Richmond, Contextual Thinking: Why Law Students (and Lawyers) Need to Know History, 42 Wayne L. Rev. 1603, 1608-1609 (1996). The criticism is not that law students do not know the legal precedents; they do not know the full meaning of the problem the rule was originally created to solve. They stop at the surface rendering of the rule without learning how the author intended it to operate, and thus the intended limits of its operation.
} 
has become a recurring theme in critiques of legal education. Law, writes Philip Kissam,

teaches instrumental habits of reading and writing that both empower and limit future lawyers. These habits consist of quick, productive but often superficial ways of reading legal texts and writing about law, and they are linked to the law school's distinctive oral culture, which celebrates oral heroism and tacitly devalues complex reading and writing. ${ }^{102}$

By such means does the student acquire the psychological posture of an initiated professional, which can include comparatively less attention to both the past and the future. She instead immerses herself in resolving the knotted problems offered by the client immediately in front of her, no less but no more.

It must be emphasized that this alleged broad trait- that lawyers tend to put greater value on present issues, letting both the past and the future fend for themselves - should not be construed as a lapse. The argument is that American attorneys adopt this view because on the whole this method produces a highly effective system of law. In this way the client can be confident of the undivided loyalty of his hired lawyer, a relationship of faith and trust that assures a fair and vigorous presentation of his arguments. Our project asks what happens when these habits of mind, productive and sensible in their home environment, are carried over into foreign settings.

If lawyers focus on the present to the relative exclusion of both past and future, librarians by virtue of their own ethical obligations tend to view all three temporal horizons simultaneously. While they collect the past in order to serve the present patron, librarians also have an acknowledged duty to the future library user. This commitment is created through the inclusion of preservation within the published codes of ALA ${ }^{103}$ and AALL. ${ }^{104}$ Michael Gorman incorporates this idea within his central values of librarianship: Stewardship includes "preserving the human record to ensure that future generations know what we know," and while there may be other kinds of information professionals, librarians are the only ones "dedicated to the preservation of recorded knowledge and information." 105 These independent obligations can come into conflict. For example, some uses in the present

\footnotetext{
102 Kissam, supra n. 60, at 7.

103 Am. Libr. Assoc., Code of Ethics, available at http://www.ala.org/advocacy/proethics/ codeofethics/codeethics ("We significantly influence or control the selection, organization, preservation, and dissemination of information").

104 Am. Assoc. L. Libr., Ethical Principles, Preamble, http://www.aallnet.org/ main-menu/Leadership-Governance/policies/PublicPolicies/policy-ethics.html ("By collecting, organizing, preserving, and retrieving legal information, the members of the American Association of Law Libraries enable people to make this ideal of democracy a reality").

105 Michael Gorman, Our Enduring Values: Librarianship in the $21^{\text {st }}$ Century 26, 59 (2000).
} 
must be prevented in order to preserve the materials for the future. In such instances, "librarians must bring their experience and judgment to bear on each case in order to arrive at the best solution, always bearing in mind that the constituency ... includes future generations." "106

The final section makes an initial empirical assessment of the significance of this value divergence for law librarianship.

\section{The AALL Demographic}

The preceding section offered the theoretical rationale justifying the prediction that lawbrarians-those schooled first as lawyers, and then as librarians_-will be distinguishable from libyers-librarians who subsequently attended law school—on more than educational biography. This section examines the empirical support for this general claim.

Method. AALL members from the 2010-2011 print membership directory were transcribed into an Excel spreadsheet, producing 4242 names. ${ }^{107}$ Although AALL no longer routinely publishes its membership rates, its Executive Board recently reported the official membership tally for 2010-11 as 4905. ${ }^{108}$ Recorded information included each member's name, email address, and place of employment.

Names were then searched in the online AALL directory, which allows members to provide complete educational backgrounds. This opportunity, unfortunately, is one of which a sizeable percentage of librarians does not take advantage. Where sufficient details were lacking, an attempt was made to fill the gap by searching institutional and other websites.

These data were used to code librarians as one of the following:

0 (lacking both library and law degrees)

1 (holding only the library degree)

2 (dual-degree, library degree first - the libyer)

3 (dual-degree, law degree first - the lawbrarian)

4 (holding only the law degree)

106 Assoc. C. \& Res. Inst., Code of Ethics for Special Collections Librarians, Preamble, http://www.rbms.info/standards/code_of_ethics.shtml.

107 This version of the directory was the most current when the present project was begun. The author thanks Steven Richardson for his assistance in collecting the data for this section. 108 Am. Assoc. L. Libr., Membership Statistics 2009-2013 (Nov. 2013), http://aallnet. org/main-menu/Leadership-Governance/executiveboard/meetings/boardbooks/2013/

5yrmemstats.pdf.aspx. In addition to the possibility that names failed to be transferred to the spreadsheet, a more likely alternative explanation for the shortfall between the two counts is that many members have exercised the offered option to have their profiles excluded from the directory. As no systematic pattern of omission has been detected, the acquired sample should be judged representitive of AALL members as of July 1, 2010. 
TABLE 1 Educational profiles of AALL members, 2010-2011

\begin{tabular}{|c|c|c|c|c|c|c|c|}
\hline & \multirow[b]{2}{*}{ Total number } & \multirow[b]{2}{*}{ Number rated } & \multicolumn{5}{|c|}{ Educational backgrounds } \\
\hline & & & 0 & 1 & 2 & 3 & 4 \\
\hline $\begin{array}{l}\text { AALL } 2011 \text { Salary } \\
\text { Survey }{ }^{109}\end{array}$ & 3337 & & & $\begin{array}{c}\text { Total: } 48.3 \% \\
\text { Academic: } 33.1 \%\end{array}$ & $\begin{array}{r}\text { Total: } \\
\text { Academi }\end{array}$ & $\begin{array}{l}33.2 \% \\
\text { ic: } 55.1 \%\end{array}$ & $\begin{array}{c}\text { Total: } 5.9 \% \\
\text { Academic: } 5.8 \%\end{array}$ \\
\hline AALL combined & 4242 & $2713(64 \%)$ & 124 & $1431(52.7 \%)$ & $350(12.9 \%)$ & $695(25.6 \%)$ & $113(4.2 \%)$ \\
\hline $\begin{array}{c}\text { Academic law } \\
\text { librarians }\end{array}$ & $\begin{array}{c}1813 \\
\text { (43\% of AALL) }\end{array}$ & $\begin{array}{c}1380 \\
\text { (76\% of all } \\
\text { acad.) }\end{array}$ & 36 & $496(35.9 \%)$ & $255(18.5 \%)$ & $542(39.3 \%)$ & $51(3.7)$ \\
\hline $\begin{array}{l}\text { Nonacademic } \\
\text { law librarians }\end{array}$ & $\begin{array}{c}2429 \\
(57 \% \text { of AALL) }\end{array}$ & $\begin{array}{l}1333 \\
\text { (55\% of all } \\
\text { nonacad.) }\end{array}$ & 88 & $935(70.1 \%)$ & $95(7.1 \%)$ & $153(11.5 \%)$ & $62(4.7 \%)$ \\
\hline
\end{tabular}

Several coding decisions were necessary due to the vagueness with which many individuals publically describe their educational attainments, such as reporting degrees but no dates. This lack of detail rendered it difficult to objectively determine which had been attained first. In order to assure coding consistency, the following decision rules were applied:

1. Those for whom no information was available, and who are not now in the AALL online directory, were scored " 0 "; and

2. If degree order could not be definitively determined by either explicit statement or inferred from biographical accounts (e.g., profile information completed, but does not report any bar memberships, supporting an inference that individual never practiced, and thus presumptively attained law degree after library degree), this was scored "2."

In addition, whenever both degrees were awarded in the same year, the item was scored as " 2 ," under the rationale that the tested hypotheses refer to rank-ordered acquisition, not simultaneous, and thus these circumstances were treated in a way that cut against the hypothesized outcome.

Results. Summary data of the investigation into AALL membership educational training appear in Table 1. For comparison, the first row reports the published figures from the 2011 AALL Salary Survey.

\section{AALL GENERALLY}

Educational backgrounds were identified for 2713 of the 4242 recorded AALL members. One hundred and twenty-four reported neither a library nor a law degree, and 1431 held only the library credential. A small number, 113, work in law libraries with only a law degree. Significantly for present purposes, 1045 of all profiles, or approximately 38\% of the librarians for whom graduate educational information is available, self-report as having both degrees. This result fits well with the figure of $33.2 \%$ published by AALL. Because the Salary 
Survey estimates are closely replicated in the present study, the procedures used to generate the figures can be regarded as reliable.

The refined coding of the collected data permits pushing deeper into the observed patterns. Of those 1045 dual-degreed librarians, 350 earned first the library degree and then the law degree, while 695 pursued the reverse pattern, attaining first the law, and later the library degrees. In AALL as a whole, the latter group, the lawbrarians, outnumber libyers by two to one.

\section{The Academic Subset Versus all Other Law Librarians}

According to the figures in Table 1, 57.8\% of librarians working in academic environments hold both law and library degrees. This result again closely approximates the finding of $55.1 \%$ reported in the most recent AALL Salary Survey, further supporting the validity of the present study's method. ${ }^{110}$

While the proportion of lawbrarians to libyers is relatively consistent among both academics and non-academics - approximating the aggregate 2:1 ratio - the absolute numbers of each are much higher among academics. This is because most nonacademic law librarians hold only the MLS. The $57.8 \%$ of dual-degreed academics thus far outpaces the $18.6 \%$ among nonacademics.

In sum, if the claim is sound that educational background influences the way we respond to professional problems, then these figures suggest that academic environments will foster consistent value differences when compared with other law library contexts, such as courts or law firms. While some portion of any observed discrepancies can be attributed to the varying priorities of the work environments, the present argument is that some residual can be independently ascribed to the preponderance of lawbrarians in academic environments as opposed to the librarians in all others.

\section{Years Between First and Second Degrees}

Evidence of the hypothesized divergence between libyers and lawbrarians may appear long before the conferring of the second degree. Looking at only those records for which exact graduation dates could be identified, we are able to calculate the span between the two conferments.

As shown in Table 2, on first reading libyers spend about two more years with a single degree before deciding to expand their credentials than do lawbrarians. When corrected for the typical length of time of time to complete respective programs-3 years for law, 1.5 for library school—we

$110 \quad I d$ 
TABLE 2 Average years between earned degrees

\begin{tabular}{lccc}
\hline & $\begin{array}{c}n \text { (exact degree dates found; } \\
\text { difference }>0>\text { ) } \\
\text { (libyers/lawbrarians) }\end{array}$ & Libyers ("2") & Lawbrarians (“3”) \\
\hline AALL combined & $241 / 624$ & $8.0(5.0)$ years & $6.1(4.6)$ years \\
Academic law librarians & $176 / 477$ & $8.0(5.0)$ years & $5.8(4.3)$ years \\
Nonacademic law & $65 / 148$ & $7.9(4.9)$ years & $6.9(5.4)$ years \\
librarians & & & \\
\hline
\end{tabular}

see that lawyers are more likely to change careers before librarians. The difference, however, is small. Across the board librarians tend to initiate the transition after about five years in their original track, while the timing for lawyers ranges from 4.3 to 5.4 years.

There appears, therefore, to be a small but consistent tendency for lawyers to transition into lawbrarians sooner in their personal careers than for librarians to become libyers.

\section{Practical Impacts}

Not all differences make a difference. It may well be the case that even if everything argued earlier is true, that the effect described is too weak to matter in the ordinary workings of libraries. The collected data suggest two ways that the tendencies identified might influence real operations.

\section{The Durham STATEMENT}

Drafted on February 11, 2009, the Durham Statement signaled a growing movement to encourage open access scholarship initiatives within legal scholarship. The outcome of a session convened by Richard Danner at Duke University, the document observes that scholars now access journal articles more frequently in electronic format than on paper, and that maintaining these dual formats imposes an unnecessary burden on libraries in terms of both money and space. In light of these facts, the Durbam Statement concludes by urging all law schools—unlike other academic disciplines, the primary journals in law are published by law schools and edited by students- to make "definitive versions of journals and other scholarship produced at the school immediately available upon publication in stable, open, digital formats." 111 The manifesto's more controversial prong, however, goes

111 Durham Statement, Feb. 11, 2009, http://cyber.law.harvard.edu/publications/durhamstatement. 
TABLE 3 Educational profiles of AALL signers of Durham Statement

\begin{tabular}{|c|c|c|c|c|c|c|}
\hline & \multirow[b]{2}{*}{ Average rank } & \multicolumn{5}{|c|}{ Educational backgrounds } \\
\hline & & 0 & 1 & 2 & 3 & 4 \\
\hline AALL member statement signers $(n=55)$ & 2.42 & 0 & 9 & 15 & 30. & $\frac{1}{\%}$ \\
\hline AALL total $(n=2713)$ & 1.72 & 124 & 1431 & 350 & $\begin{array}{l}695 \\
29 .\end{array}$ & $\begin{array}{l}113 \\
\%\end{array}$ \\
\hline
\end{tabular}

on to call for law schools to cease completely publication of those titles in print. ${ }^{112}$

The Durham Statement has gained significant influence within law librarianship. ${ }^{113}$ Formally, however, the document has been signed by only seventy-five individuals. Internet searching identified twenty of the signers as law professors and legal practitioners who are not included in the AALL membership directory. Excluding these, Table 3 compares the remaining fifty-five signing AALL members with the general AALL educational background ratings.

As a group, signers are more likely than the AALL general membership to have received a legal education, and to have received it before completing their training as librarians. Fifty-six percent of signers are category 3 "lawbrarians" or law-trained-only category $4 \mathrm{~s}$, while the corresponding rate for these two groups within AALL at-large is less than thirty percent.

Disproportionately more lawbrarians over libyers view the conclusions of the Durbam Statement as a positive direction sufficiently to attach their names to the text. The earlier conclusion that legal practice encourages assigning a greater priority to present over future needs provides reasonable interpretive context to this finding. Lawbrarians would be expected to accept that present access behaviors should receive greater support than preservation for the future. ${ }^{114}$ The contrary view would hold that a "reexamination of the recommendation to cease print publication (of law reviews, or any truly

$112 I d$. ("We therefore urge every U.S. law school to commit to ending print publication of its journals").

113 See, e.g., Richard A. Danner, Kelly Leong, \& Wayne V. Miller, The Durham Statement Two Years Later, 103 L. Libr. J. 39 (2011).

114 To be fair, the Durbam Statement does anticipate electronic substitutes will be made available on "agreed-upon stable, open, digital formats," which could conceivably address any preservation concerns. The problem, unfortunately, is that such formats do not yet exist. The statement does not counsel discontinuing print publication once such stable formats for permanent archives become available; the implicit suggestion is that journals should take this step immediately. To implement the Durham Statement before technology achieves a more sophisticated level is to risk losing the earlier content, and thus fail in the librarian's duty to the future. 
important category of information) should take a long view, both backward into history and forward into future possibilities." 115

We see in these debates how collection development positions can be influenced by the temporal horizon one applies to define the range of responsible practice. This case may serve as an example of the how practical situations may be influenced by the predispositions acquired during professional school indoctrination.

The data, however, raise another question. For a position paper publicly endorsed by only seventy-five individuals, the Durbam Statement has generated considerable buzz out of all relationship to the number of its formal subscribers. To explain such disproportionate influence, we can certainly look to the document's original framers, directors of some of the country's most important academic law libraries. ${ }^{116}$ In fact, of the fifty-five AALL signers, thirty-one are library directors. We may then ask how academic law library directors as a group compare with the general AALL membership on the variable of the present study.

\section{DIRECTORS}

While academic law library directors constitute a very small percentage of librarians (as of this writing, there are 203 ABA-approved law schools, ${ }^{117}$ which limits the maximum number of possible directors), by virtue of their status they exert powerful influences not only within their own institutions

115 Margaret A. Leary, A Response to The Durham Statement Two Years Later, 103 L. Libr. J. 281, 282 (2011). Leary qualifies as a libyer.

116 The schools represented by the Durham Statement's authors are Duke, New York University, Harvard, Cornell, University of Pennsylvania, Northwestern, Yale, Stanford, University of Chicago, and University of Texas. Interestingly, these schools are perhaps the least likely to be influenced by the rationale underlying the Durbam Statement. Their flagship journals are the ones most likely, if any, to turn a profit in their operations, and thus be the least motivated to eliminate that revenue stream by ceasing print publication. See Richard A. Danner, Kiril Kolev \& Marguerite Most, Print or Perish? Authors' Attitudes toward Electronic-Only Publication of Law Journals 1, 13, July 15, 2011, http://papers.ssrn.com/sol3/papers.cfm?abstract_id=1886445 ("it may be that because of their large print subscriber bases, or endowments and other sorts of outside income or funding, the 'fanciest' journals feel the least pressure to discontinue publication of print issues"). They are thus in the awkward position of asking others to eliminate print editions, which they would most likely retain, further disadvantaging less prestigious schools in the competition for top submissions in a market that still values the prestige of a print publication. Id. at 12 ("given the chance to publish in more than one of these prestigious journals, other than those they considered to be the most prestigious, more than half of these authors indicated that continuing publication of print issues would be the deciding factor in choosing which offer to accept").

117 Am. Bar Assoc., ABA-Approved Law Schools, http://www.americanbar.org/groups/ legal_education/resources/aba_approved_law_schools.html. 
TABLE 4 Director/nondirector comparison in academic law libraries

\begin{tabular}{lcccccc}
\hline & & \multicolumn{4}{c}{ Educational backgrounds } \\
\cline { 4 - 7 } & Average rank & 0 & 1 & 2 & 3 & 4 \\
\hline Directors $(n=187)$ & 2.55 & 0 & 7 & 72 & 106 & 2 \\
Nondirectors $(n=1193)$ & 1.97 & 36 & 489 & 183 & 436 & 49 \\
Librarians within academic settings $(n=1380)$ & 2.05 & 36 & 496 & 255 & 542 & 51 \\
\hline
\end{tabular}

but also throughout the profession. If directors are disproportionately either libyers or lawbrarians, and if these types carry the ramifications suggested, then the order of graduate training can impact not only personal careers, but the profession as a whole.

Table 4 compares education profile ratings of academic law library directors with all other librarians working in academic environments. Unsurprisingly, directors are far more likely to hold dual degrees than are nondirectors (95.2\% versus $51.9 \%)$. An unexpected finding is that the rate of lawbrarians, while higher in absolute numbers within both populations, is lower as a percentage of the dual-degreed subset among directors. Thus, of 178 dualdegreed directors, $59.6 \%$ are lawbrarians, while the matching rate among the 619 nondirectors is $70.4 \%$. Libyers, in other words, are overrepresented among directors, suggesting that whatever the differences may be, hiring committees may appreciate the constellation of traits of the librarian-turnedlawyer in this particular position.

Although overrepresented, libyers are still the minority profile for directors of academic law libraries. As lawbrarians predominate in the highest positions within these professionally influential institutions, any socializationbased tendencies would yield a greater influence than mere numbers might predict. Not only do they set precedential policies emulated by others, but they are then often nominated to lead AALL itself. Should future studies looking at AALL presidents and executive board members reveal them to be disproportionately one or the other, we may then uncover a feasible mechanism for the effects of individual educational sequencing to subtly tilt the direction of the profession. A suggestive hint of this process appears when comparing the data of these two data sections: While on the whole directors have a libyer/lawbrarian ratio of 1:1.5, the ratio among Durham Statement signers is 1:2. When acting in concert, even minute predispositions can lead to major policy changes.

\section{CONCLUSION}

The argument has been made that dual-degreed law librarians can be distinguished by the order in which they received their law and law degrees. One's 
first experience of professional socialization will have a more profound influence on broad interpretative preferences, which can generate divergent default predispositions on matters of mutual interest to both lawyers and librarians. This model appears to be supported by the pattern of educational achievement among members of AALL.

The previous sections should be read together. Without the data, the theory section is idle speculation; without the theory, the data offer only a bald description from which nothing can be concluded or generalized. But because the data are predicted by the outlined theory, in combination they offer a reasonable explanation for the reported relationships. We don't just notice them, we potentially understand them.

One immediate impact of the analysis of professional education sequences relates to current debates over the desirability of the dual degree for law librarians. ${ }^{118}$ When one looks only at surface demographics, dualdegreed law librarians appear to be the majority within academic settings. That reality can give rise to a perception that librarians are being pushed to shoulder an unacceptable financial burden to acquire the law degree and thereby advance their careers.

The deeper analysis, however, shows such concerns to be exaggerated, if not misplaced. Most dual-degreed law librarians are not librarians who enroll in law school, but instead lawyers who, after about four or five years of practice, find themselves unsatisfied and seek out librarianship as an alternative environment in which to apply their skills and knowledge. Given the current market for JDs, we may expect this trend to continue if not increase. The financially ruined librarian is a minority, and certainly not a sufficient basis on which to call to eliminate the dual degree as a preferred qualification for at least public service academic librarians. If there are serious reasons to deemphasize the MLS-JD combination, the economic burden on librarians is not one of them.

Of more lasting significance are the ways in which variable professional credentialing may exert subtle but nonetheless consistent influences on the direction of the discipline. Professional education by its very nature, with the intent to socialize the student into a community of practitioners, is as heavily involved in the project of identity and ethical formation as it is in skills training. Professionalism is not simply a role one learns to perform-although there is certainly some of that-but rather a way of seeing one's self, and one's relationship to the rest of society. One can be an impeccable courtroom practitioner, and still be thrown into professional disrepute for behaving in other ways and parts of life that bring shame to the public identity of the lawyer - an additional burden not expected to be shouldered by, say, plumbers or chefs. If we accept this conclusion from the literature, then 
the formative impact of professional training would be neither negligible nor easily thrown off. Sequence of exposure to multiple regimes of professional training, and not merely their presence or absence, can skew the final outcome.

These tendencies pertain to groups; not every individual qualifying as a "lawbrarian" or a "libyer" will fit the generalized description. However, possessing only information about the sequence of professional degree achievement, these qualities would serve as justified starting points to predict future predispositions. Any such group distinctions, however, would not favor preference for one over the other. Lawbrarians and libyers are different but equally legitimate ways of being law librarians. But neither should we ignore patterns within our membership. Rather, we should seek to find ways to employ them effectively. In the end, it is likely we will find that we need both types of librarians in order to generate a sufficient diversity of viewpoints to arrive at the optimal approach to any particular problem.

Uncertainty over the correct balance between print and electronic formats may be one context in which we see these tendencies currently playing out. Arguably, lawbrarians, as they learned in law school to be the proper balance, will be more likely satisfied to address present demands with electronic, often leased materials, and let the future largely take care of itself; libyers, again as a group, will perhaps wish to weigh the needs of future readers equally with the convenience of present ones, and thus potentially reach a different conclusion concerning the best practices for collection development. Other points of conflict can be anticipated.

The dual-degreed librarian has become a standard feature of the law library landscape. To a large extent we have taken this subset as too familiar and uncomplicated to merit extended attention. The present study has shown that more than their numbers, the special elements of professional education produce an outcome that defies the commutative property of addition. ${ }^{119}$ Order matters; we must begin to better study these undercurrents of our profession.

119 The commutative property refers to the "condition that a group of quantities connected by operators gives the same result whatever the order of the quantities involved, e.g., $a \times b=$ b x a." New Oxford American Dictionary 347 (2001). 